\title{
Evaluation of physical and mechanical properties of quarry stones in the southern Republic of Benin
}

\section{Bouraima Mouhamed Bayane *, Qiu Yanjun **}

* Southwest Jiaotong University,

Chengdu, Sichuan 610031, China

School of Civil Engineering

** Southwest Jiaotong University,

Chengdu, Sichuan 610031, China

Key Laboratory of Highway Engineering, Sichuan Province

\section{open 2 access (c) dol}

\section{Article history:}

Received: April, 2017

1st Revision: April, 2017

Accepted: May, 2017

\section{DOI:}

10.14254/jsdtl.2017.2-1.6

\begin{abstract}
Engineering properties of stones have a crucial importance when they are used for civil engineering works. In this study, the suitability of rocks blocks or stones as a construction material is established. Cove and Dan cities surroundings in the southern part of Zou Province have large blocks and aggregates quarries operated recently. In this study, laboratory tests were carried out to investigate the performance of rocks blocks and aggregates quarried in the region. For this purpose of the study, three wooden containers with rocks blocks and aggregates samples were collected from three different quarries, and so, laboratory tests including particle density and water absorption test, resistance to wear, magnesium sulfate test, compressive strength and methylene blue absorption test were performed in accordance with the international standards to explore the quality of stones to be used for modern construction. Concluding that rocks blocks and aggregates satisfy the relevant regulation (that is, a norm, European standard).
\end{abstract}

Keywords: engineering properties, rocks blocks, aggregates, construction material, Republic of Benin.

\section{Introduction}

Benin has an area of 114,763 square $\mathrm{km}$ and a population around 10.88 million that use a 15,700 $\mathrm{km}$ of road network throughout the country. From 1996 to 2001 period, the government took many initiatives and operated some change in administration in order to remodel and reconstruct all the national highways of the republic of Benin to provide the safe and efficient network. In general, it is well known that better roads are considered as a necessary component of the government's poverty eradication approaches that operate as a mechanism to reduce unemployment (Khan, 2008). According to estimates, the road transport sector carries between 80 to $90 \%$ of passengers and goods

Corresponding author: Bouraima Mouhamed Bayane

E-mail: soulsafmob@my.swjtu.edu.cn

This open access article is distributed under a Creative Commons Attribution (CC-BY) 4.0 license. 
and it is the only means of access to most rural communities. Then we can understand the importance of the road and especially its maintenance in the development of our country. Therefore, acquire a lot of aggregates for the extension and the maintenance of road network is a priority for highways construction industries. Aggregate is the very fundamental material in pavement construction which properties mostly influence the pavement performance.

For pavement construction, a huge quantity of aggregates is sine qua non (Smith \& Collis, 2001). In the republic of Benin, aggregates are produced mainly by quarrying rocks and then crushing to required sizes for use in ordinary asphalt pavement layers, water bound macadam and railway ballast. Besides these, gravel and sand produced by natural processes are used as aggregates (Neville \& Brooks, 1999; Kandhal et al., 2000; Zaidi et al., 2008). The in-service performance of all those abovementioned structures is linked with engineering properties of aggregates (Neville, 2000). The engineering performance of construction materials is strongly connected to their physical properties (Krynine \& Judd, 1998). Studies on the compressive strength of certain rock aggregates for the Nigerian Basement rocks (Akpokoje, 1992) found that the aggregates are good engineering materials based on both compressive strength and water absorption characteristics.

The extension of road network needs a huge quantity of durable and cheap aggregates. Properties of aggregates are very important in the selection of good quality and performance bound aggregate for use in construction (Ahsan et al., 2000; Fookes et al. 1988). The purpose of this study is to clarify the links between geomechanical properties (that is physical and mechanical) of construction stones and their quality to use as civil engineering works. It is certain that information regarding physical and mechanical properties of stones and rocks blocks, taking cognizance of compositional characteristics, will enable a better appreciation of geological fundamentals in engineering practice.

\section{Materials and Testing}

The materials for laboratory evaluation were acquired from Cove and Dan quarries by two companies (Serm and Adeoti). Serm (Société d'extraction des ressources minires) quarry is at Dan city and Adeoti quarries are based on both Cove and Dan cities. The aggregates used in pavement construction must be durable, clean and tough to resist weathering and crushing. In order to meet the requirements standards, particle density and water absorption (EN 13383-2), micro-Deval test (EN 1097-1), magnesium sulfate test (EN 1367-2), compressive strength test (EN 1926) and methylene blue absorption test (Verhoef, 1992)

First of all, particle density and water absorption test were conducted on the aggregates and rocks blocks from Dan and Cove. The tests are executed on the samples: Serm-Rho-WA, AD-WA-Rho, and AC-Rho-WA. The individual aggregates samples were tested in 10 samples to determine the particle density. The minimum limit of the particle density according to the European standard is $2.6 \mathrm{t} / \mathrm{m}^{3}$ and the maximum limit for water absorption is $2 \%$.

Toughness is the resistance of aggregate to impact. Aggregates used in the pavement should be able to resist the effect caused by jumping of the steel tire wheels from one particle to another at different levels causing severe impact on the aggregates. In order to check the toughness, the microDeval test was performed. The test consists of measuring the wear produced by friction between aggregates and an abrasion charge in a rotating drum under defined conditions. In the test, the aggregate size range is $10 \mathrm{~mm}$ to $14 \mathrm{~mm}$. the tests are executed on samples: Serm-MgSO4-Mde and ACMde. AD-Mde did not contain suitable aggregate in the $10 \mathrm{~mm}$ to $14 \mathrm{~mm}$ size range. For this sample two test portions were prepared in accordance with EN 1097-1: 1996, clause 6 with the variations specified in 5.4.1, 5.4.2 and 5.4.3 of EN 13383-1:2002. The broken rock pieces were crushed in a laboratory jaw crusher to size 10-14 mm. The flaky particles were removed using bar sieve $6.3 \mathrm{~mm}$ and for fractions 12.5 to $14 \mathrm{~mm}$ removing particles which passing bar sieve $8 \mathrm{~mm}$. Also, the cubical particles were removed by using the bar sieve $12.5 \mathrm{~mm}$ for the fraction $12.5 \mathrm{~mm}$ to $14 \mathrm{~mm}$. The maximum limit of the micro-Deval test is $20 \%$.

The magnesium sulfate test describes the reference method used for type testing and in the case of dispute for assessing how an aggregate behaves when subjected to the cyclic action of immersion in magnesium sulfate followed by oven drying. The test is done on aggregate in the $10 \mathrm{~mm}$ to $14 \mathrm{~mm}$ size range. The tests are executed on sample: Serm-MgSO4-Mde, AD-MgSO4, and AC-MgSO4. For sample Serm-MgSO4-Mde and AC-MgSO4, the test was executed on provided $10 \mathrm{~mm}$ to $14 \mathrm{~mm}$ aggregate. 
Sample AD-Mde did not contain suitable aggregate in the $10-14 \mathrm{~mm}$ range by a jaw crusher. The European standard test EN 1367-2 specifies a maximum of $10 \%$ after 5 cycles.

The methylene blue absorption test is used to quantify the amount of clay mineral (smectite group) present in quarried rock. The tests are executed on sample: mix sample (Serm), mix sample (AC), mix sample (AD). A part of each sample was grained to a fine powder in a mechanical pestle and mortar. The maximum limit value is $0.7 \mathrm{~g} / 100 \mathrm{~g}$ absorption.

The compressive strength test (EN 1926) specifies a method for determining the strength of natural stones. In this test, the specimen shall be tested in a saturated condition, in their weakest orientation with respect to any existing plane of anisotropy. Each specimen was prepared from a separate rock block. The axes of the specimens are parallel to the planes of anisotropy, foliations.

\section{Results and discussions}

The overview test program and sample identification with the results of the particle density and water absorption, micro-Deval, magnesium sulfate and compressive strength value of the aggregates are presented in Tables 1 to 5 .

\begin{tabular}{|c|c|c|c|}
\hline $\begin{array}{c}\text { Sample identification } \\
\text { mark }\end{array}$ & Source & Required test & Number of tests \\
\hline Serm-Rho-WA & Serm quarry at Dan & $\begin{array}{c}\text { Particle density (EN } \\
13383-2 \text { ) } \\
\end{array}$ & 10 \\
\hline Serm-Rho-WA & Serm quarry at Dan & $\begin{array}{c}\text { Water absorption (EN } \\
13383-2)\end{array}$ & 10 \\
\hline Serm-MgSO4-Mde & Serm quarry at Dan & $\begin{array}{c}\text { Resistance wear (micro- } \\
\text { Deval) (EN 1097) }\end{array}$ & 1 (Duplo test) \\
\hline Serm-MgSO4-Mde & Serm quarry at Dan & $\begin{array}{l}\text { Magnesium sulfate test } \\
\text { (EN 1367-2) }\end{array}$ & 1 (Duplo test) \\
\hline Serm-UCS & Serm quarry at Dan & $\begin{array}{c}\text { Compressive strength (EN } \\
1926 \text { ) }\end{array}$ & 10 \\
\hline Mix sample (Serm) & Serm quarry at Dan & $\begin{array}{l}\text { Methylene Blue test } \\
\text { (Verhoef 1992) }\end{array}$ & 1 \\
\hline AC-Rho-WA & Adeoti quarry at Cove & $\begin{array}{c}\text { Particle density (EN } \\
13383-2 \text { ) }\end{array}$ & 10 \\
\hline AC-Rho-WA & Adeoti quarry at Cove & $\begin{array}{c}\text { Water absorption (EN } \\
13383-2 \text { ) }\end{array}$ & 10 \\
\hline AC-Mde & Adeoti quarry at Cove & $\begin{array}{c}\text { Resistance wear (micro- } \\
\text { Deval) (EN 1097) }\end{array}$ & 1 (Duplo test) \\
\hline AC-MgSO4 & Adeoti quarry at Cove & $\begin{array}{l}\text { Magnesium sulfate test } \\
\text { (EN 1367-2) }\end{array}$ & 1 (Duplo test) \\
\hline AC-UCS & Adeoti quarry at Cove & $\begin{array}{c}\text { Compressive strength (EN } \\
1926 \text { ) }\end{array}$ & 10 \\
\hline Mix sample (AC) & Adeoti quarry at Cove & $\begin{array}{l}\text { Methylene Blue test } \\
\text { (Verhoef 1992) }\end{array}$ & 1 \\
\hline AD-Rho-WA & Adeoti quarry at Dan & $\begin{array}{c}\text { Water absorption (EN } \\
13383-2 \text { ) }\end{array}$ & 10 \\
\hline AD-Rho-WA & Adeoti quarry at Dan & $\begin{array}{c}\text { Water absorption (EN } \\
13383-2 \text { ) }\end{array}$ & 10 \\
\hline AD-Mde & Adeoti quarry at Dan & $\begin{array}{c}\text { Resistance wear (micro- } \\
\text { Deval) (EN 1097) }\end{array}$ & 1 (Duplo test) \\
\hline AD-MgSO4 & Adeoti quarry at Dan & $\begin{array}{l}\text { Magnesium sulfate test } \\
\text { (EN 1367-2) }\end{array}$ & 1 (Duplo test) \\
\hline AD-UCS & Adeoti quarry at Dan & $\begin{array}{c}\text { Compressive strength (EN } \\
1926 \text { ) }\end{array}$ & 10 \\
\hline Mix sample (AD) & Adeoti quarry at Dan & $\begin{array}{l}\text { Methylene Blue test } \\
\text { (Verhoef 1992) }\end{array}$ & 1 \\
\hline
\end{tabular}




\begin{tabular}{|c|c|c|c|c|c|c|c|c|c|c|c|}
\hline $\begin{array}{l}\text { Sample: } \\
\text { Serm }\end{array}$ & S1 & S2 & S3 & S4 & S5 & S6 & S7 & S8 & S9 & S10 & Total \\
\hline $\begin{array}{l}\text { Particle } \\
\text { density } \\
\left(\mathrm{t} / \mathrm{m}^{3}\right)\end{array}$ & 2.63 & 2.63 & 2.63 & 2.63 & 2.63 & 2.63 & 2.63 & 2.63 & 2.63 & 2.63 & 2.63 \\
\hline $\begin{array}{l}\text { Water } \\
\text { absorption } \\
(\%)\end{array}$ & 0.18 & 0.16 & 0.16 & 0.24 & 0.17 & 0.16 & 0.15 & 0.18 & 0.18 & 0.20 & 0.18 \\
\hline $\begin{array}{c}\text { Sample: } \\
\text { Adeoti-Cove }\end{array}$ & A1 & A2 & A3 & A4 & A5 & A6 & A7 & A8 & A9 & A10 & \\
\hline $\begin{array}{l}\text { Particle } \\
\text { density } \\
\left(\mathrm{t} / \mathrm{m}^{3}\right)\end{array}$ & 2.74 & 2.87 & 2.67 & 2.78 & 2.76 & 2.74 & 2.82 & 2.81 & 2.75 & 2.68 & 2.76 \\
\hline $\begin{array}{l}\text { Water } \\
\text { absorption } \\
(\%)\end{array}$ & 0.08 & 0.07 & 0.09 & 0.09 & 0.13 & 0.10 & 0.02 & 0.13 & 0.08 & 0.11 & 0.09 \\
\hline $\begin{array}{c}\text { Sample: } \\
\text { Adeoti-Dan }\end{array}$ & D1 & D2 & D3 & D4 & $\begin{array}{l}\text { D5, light } \\
\text { grey }\end{array}$ & $\begin{array}{l}\text { D6, light } \\
\text { grey }\end{array}$ & D7 & D8 & D9 & D10 & \\
\hline $\begin{array}{l}\text { Particle } \\
\text { density } \\
\left(\mathrm{t} / \mathrm{m}^{3}\right)\end{array}$ & 2.76 & 2.77 & 2.78 & 2.78 & 2.64 & 2.63 & 2.78 & 2.78 & 2.78 & 2.62 & 2.73 \\
\hline $\begin{array}{l}\text { Water } \\
\text { absorption } \\
(\%)\end{array}$ & 0.12 & 0.14 & 0.23 & 0.12 & 0.20 & 0.20 & 0.12 & 0.13 & 0.12 & 0.18 & 0.16 \\
\hline
\end{tabular}

From Table 2, it can be seen that the particle density and water absorption of the three different sources are fulfilling the European standards and can be used for pavement construction.

\begin{tabular}{|c|c|c|c|c|c|c|}
\hline Sample & $\begin{array}{c}\text { Serm, } \\
\text { sample } 1\end{array}$ & $\begin{array}{c}\text { Serm, } \\
\text { sample 2 }\end{array}$ & $\begin{array}{c}\text { Adeoti } \\
\text { Cove, } \\
\text { sample } 1\end{array}$ & $\begin{array}{c}\text { Adeoti } \\
\text { Cove, } \\
\text { sample } 2\end{array}$ & $\begin{array}{c}\text { Adeoti Dan, } \\
\text { sample } 1\end{array}$ & $\begin{array}{c}\text { Adeoti Dan, } \\
\text { sample } 2\end{array}$ \\
\hline \multirow{2}{*}{$\begin{array}{l}\text { Micro-Deval } \\
\text { value (\%) }\end{array}$} & 6.1 & 6.4 & 13.1 & 11.8 & 8.4 & 8.3 \\
\hline & \multicolumn{2}{|c|}{6.25} & \multicolumn{2}{|c|}{12.45} & \multicolumn{2}{|c|}{8.35} \\
\hline
\end{tabular}

The results of the micro-Deval test from Table 3 show that all the samples have a value less than $20 \%$ which is the maximum limit of the test. It can be concluded that the samples from different quarries match the requirement of the European Standard. The Adeoti-Cove sample shows a bit low resistance to degradation and abrasion as compared to Adeoti-Dan and Serm Samples.

\begin{tabular}{|l|c|c|c|c|c|c|}
\hline \multicolumn{1}{|c|}{ Sample 4. Results of Magnesium sulfate soundness test } \\
& $\begin{array}{c}\text { Serm, } \\
\text { sample 1 }\end{array}$ & $\begin{array}{c}\text { Serm, } \\
\text { sample 2 }\end{array}$ & $\begin{array}{c}\text { Adeoti } \\
\text { Cove, } \\
\text { sample 1 }\end{array}$ & $\begin{array}{c}\text { Adeoti } \\
\text { Cove, } \\
\text { sample 2 }\end{array}$ & $\begin{array}{c}\text { Adeoti Dan, } \\
\text { sample 1 }\end{array}$ & $\begin{array}{c}\text { Adeoti Dan, } \\
\text { sample 2 }\end{array}$ \\
\hline $\begin{array}{l}\text { Magnesium } \\
\text { sulfate value } \\
(\%)\end{array}$ & 5.2 & 5.8 & 7.5 & 8.2 & 9.3 & 7 \\
\cline { 2 - 8 } & \multicolumn{2}{|c|}{$\mathbf{5 . 5}$} & \multicolumn{2}{|c|}{$\mathbf{7 . 8 5}$} & \multicolumn{2}{|c|}{$\mathbf{8 . 1 5}$} \\
\hline
\end{tabular}

In Table 4, all the samples have magnesium sulfate soundness test value less than $10 \%$ which is the maximum limit. According to the requirement, it can be said that the aggregates have fulfilled the requirement. The magnesium sulfate test shows that the Serm sample is more effective in resisting to breakdown and disintegration from the weathering. 


\begin{tabular}{|c|c|c|c|c|c|c|c|c|c|c|c|}
\hline $\begin{array}{c}\text { Sample: } \\
\text { Serm }\end{array}$ & S1 & S2 & S3 & S4 & S5 & S6 & S7 & S8 & S9 & S10 & Total \\
\hline $\begin{array}{l}\text { Compressive } \\
\text { strength R }\end{array}$ & 218.5 & 234.6 & 246.0 & 217.8 & 245.5 & 245.7 & 220.0 & 209.8 & 203.1 & 232.6 & 227.36 \\
\hline $\begin{array}{c}\text { Sample: } \\
\text { Adeoti- } \\
\text { Cove }\end{array}$ & $\mathbf{A 1}$ & $\overline{A 2}$ & A3 & A4 & A5 & A6 & A7 & A8 & A9 & A10 & \\
\hline $\begin{array}{l}\text { Compressive } \\
\text { strength R }\end{array}$ & 121.9 & 200.1 & 184.9 & 211.8 & 244.6 & 218.5 & 208.2 & 137.4 & 195.7 & 224.9 & 195 \\
\hline $\begin{array}{c}\text { Sample: } \\
\text { Adeoti-Dan }\end{array}$ & D1 & D2 & D3 & D4 & $\begin{array}{c}\text { D5,light } \\
\text { grey }\end{array}$ & $\begin{array}{c}\text { D6,light } \\
\text { grey }\end{array}$ & D7 & D8 & D9 & D10 & \\
\hline $\begin{array}{l}\text { Compressive } \\
\text { strength R }\end{array}$ & 240.2 & 220.8 & 147.6 & 219.9 & 219.3 & 219.0 & 220.0 & 178.0 & 229.6 & 243.0 & 214 \\
\hline
\end{tabular}

Table 5 shows the compressive strength results. All the values from the test are over $80 \mathrm{Mpa}$ which is the minimum requirement for the compressive strength test. It can be concluded that samples have good strength and ability regarding the results of Table 5. The compressive strength test shows that Adeoti-Cove sample compressive strength $\mathrm{R}$ is small compared to Adeoti-Dan and Serm samples. The methylene blue absorption values also fulfill the requirement for Serm, Cove and Dan samples which values are $0.45,0.59$ and 0.46 g respectively. Therefore, the rocks blocks and aggregated from Serm, Adeoti-Cove, and Adeoti-Dan is suitable for road construction projects. If these quarries are developed, they can produce cheap and durable aggregates for the southern part of Zou province of the republic of Benin.

\section{Findings and conclusions}

The present quarries at Cove and Dan can produce materials for each layer of pavement construction and other related civil engineering works. These potential quarries sites are easy to access through the existing road network. For south part of the Republic of Benin, the aggregates from those quarries will be cheap due to less transportation cost and due to the closeness of highways projects in the area. This evaluation can conclude:

- The areas under study can produce suitable materials for pavement and civil engineering works for construction.

- With the development of these quarries, the highways industries will get cheap construction materials and will bring change in the socio-economic condition of the local population.

\section{Appendix A. Supplementary material}

Supplementary data associated with this article can be found, in the online version, at http://jsdtl.sciview.net

\section{Funding}

The authors received no direct funding for this research.

\section{Citation information}

Bayane, M.B, \& Yanjun, Q. (2017). Evaluation of physical and mechanical properties of quarry stones in the southern Republic of Benin. Journal of Sustainable Development of Transport and Logistics, 2(1), 61-66. doi:10.14254/jsdtl.2017.2-1.6.

\section{References}

Ahsan, N., Chaudhry, M. N., \& Majid, M. (2000). Strength Evaluation of Blends of Lawrencepur, Chenab and Ravi Sands with Lockhart and Margala Hill Limestones for use in Concrete. Special Issue Pak. Muse. Nat. Hist. Pakistan Science Foundation, 213-240. 
Akpokodje, E. G. (1992). Properties of some Nigeria rock aggregates. Journal of Mining and Geology, 23(2), 185-190.

Collis, L., \& Smith, M. R. (Eds.). (2001). Aggregates: sand, gravel and crushed rock aggregates for construction purposes. Geological Society.

Fookes, P. G., Gourley, C. S., \& Ohikere, C. (1988). Rock weathering in engineering time. Quarterly Journal of Engineering Geology and Hydrogeology, 21(1), 33-57.

Kandhal, P., Mallick, R., \& Huner, M. (2000). Measuring bulk-specific gravity of fine aggregates: development of new test method. Transportation Research Record: Journal of the Transportation Research Board, (1721), 81-90.

Khan, R. A. (2008, August). Role of construction sector in economic growth: Empirical evidence from Pakistan economy. In Proceedings of the First International Conference on Construction in Developing Countries (ICCIDC), Karachi, Pakistan (pp. 279-290).

Krynine, D. P., \& Judd, W. R. (1957). Principles of engineering geology and geotechnics: geology, soil and rock mechanics, and other earth sciences as used in civil engineering. McGraw-Hill College.

Neville, A. M., \& Brooks, J. J. (1999). Concrete Technology Longman Group UK First ISE reprint 1999 Edinburgh. UK 438p.

Neville, A.M. (2000). Properties of Concrete $4^{\text {th }}$ ed. Pearson Education Asia Pte. Ltd. Edinburgh, U.K. $844 \mathrm{p}$.

Zaidi, S. M., Rafeeqi, S. F. A., Ali, M. S., \& Khan, A. M. (2008). Aggregate characterization-an important step towards addressing construction issues in Pakistan. In First international conference on construction in developing countries (ICCIDC-I)"Advancing and integrating construction education, research \& Practice" August (pp. 4-5).

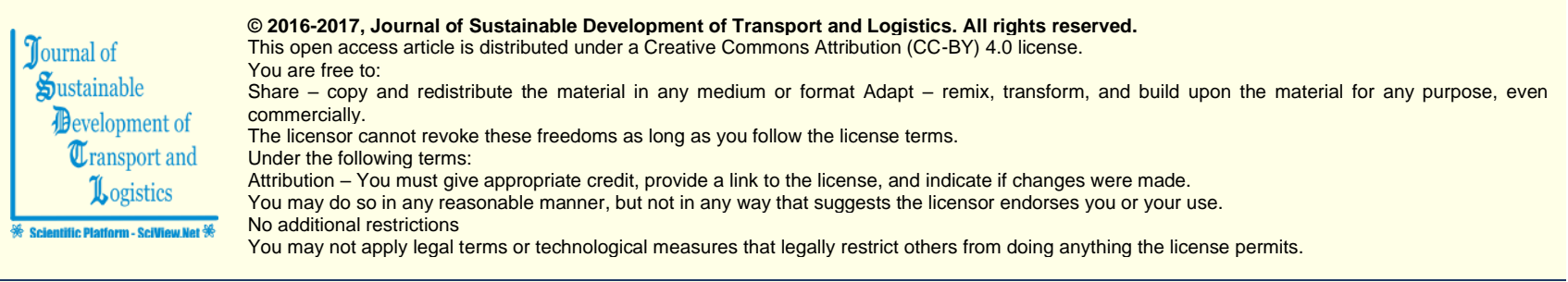

Journal of Sustainable Development of Transport and Logistics (ISSN: 2520-2979) is published by Scientific Publishing House "CSR",

Poland, EU and Scientific Publishing House "SciView", Poland, EU

Publishing with JSDTL ensures:

- Immediate, universal access to your article on publication

- High visibility and discoverability via the JSDTL website

- Rapid publication

- Guaranteed legacy preservation of your article

- Discounts and waivers for authors in developing regions

Submit your manuscript to a JSDTL at http://jsdtl.sciview.net/ or submit.jsdtl@sciview.net 